\title{
Pemikiran Pendidikan Dr. Abdullah Nashih Ulwan Dalam Mewujudkan Pemikiran Pendidikan K.H. Ahmad Dahlan
}

\author{
Anjelia Septyani ${ }^{1}$, Hudaidah ${ }^{2}$ \\ ${ }^{1,2}$ Universitas Sriwijaya \\ anjeliaseptyani333@gmail.com \\ hudaidah@fkip.unsri.ac.id
}

\begin{abstract}
Abstrak
Dalam mewujudkan pemikiran salah satu pakar pendidikan di Indonesia yaitu pemikiran $\mathrm{KH}$ Ahmad Dahlan., Dibutuhkan cakupan materi pendidikan Islam seperti yang ditulis oleh Dr. Abdullah Nashih Ulwan, dengan tujuh cakupan materi pendidikan Islam yaitu Pendidikan Iman. Pendidikan Moral/Moral, Pendidikan Jasmani, Pendidikan Rasio, Pendidikan Psikiatri/Hati Nurani, Pendidikan Sosial/Komunitas, dan Pendidikan Seksual. Penulis menggunakan metode kualitatif dan studi pustaka (Library Research). Tujuan penelitian adalah untuk mengetahui hubungan pemikiran pendidikan KH Ahmad Dahlan dengan ruang lingkup Dr. Abdullah Nashih Ulwan dalam memadukan ilmu agama dan ilmu umum. Hasil pembahasan dalam makalah ini diketahui bahwa ruang lingkup materi Dr. Abdullah Nashih Ulwan relevan dalam mewujudkan pemikiran pendidikan KH Ahmad Dahlan yang merupakan upaya strategis menyelamatkan umat Islam menuju pemikiran yang dinamis, cerdas, kritis dan memiliki daya analisis yang tajam dalam memetakan dinamika kehidupan di masa depan.
\end{abstract}

Kata Kunci: Pemikiran Pendidikan; Dr. Abdullah Nashih Ulwan; K.H. Ahmad Dahlan

\begin{abstract}
In realizing the thought of one of the education experts in Indonesia, namely the thought of KH Ahmad Dahlan., It takes a scope of Islamic education material as written by Dr. Abdullah Nashih Ulwan, with seven scopes of Islamic education material, namely Faith Education, Moral/Moral Education, Physical Education, Ratio Education, Psychiatric Education Conscience, Social/Community Education, and Sexual Education. The author uses qualitative methods and literature (Library Research). The research objective was to determine the relationship between KH Ahmad Dahlan's educational thoughts and the scope of Dr. Abdullah Nashih Ulwan in combining religious knowledge and general knowledge. The results of the discussion in this paper note that the scope of the material Dr. Abdullah Nashih Ulwan is relevant in realizing KH Ahmad Dahlan's educational thinking which is a strategic effort to save Muslims towards dynamic, intelligent, critical thinking and has sharp analytical power in mapping the dynamics of life in the future.
\end{abstract}

Keywords: Educational Thought; Dr. Abdullah Nashih Ulwan; KH Ahmad Dahlan's 
Jurnal Humanitas

Vol. 6 No. 2, Juni 2020, hal. 132-143

\section{Pendahuluan}

Pendidikan diperuntukkan kepada anak-anak dan remaja baik di sekolah maupun di kampus dengan tujuan memberikan pengetahuan dan mengembangkan keterampilan melalui tahapan pelatihan dan pengajaran (Saidah, 2016). Salah satu pakar pendidikan yang ada di Indonesia yaitu pemikiran K.H. Ahmad Dahlan, ia ditetapkan sebagai pahlawan Nasional, dengan empat alasan spesifik, yaitu sebagai pelopor bangsa untuk terus berbuat dan belajar agar merdeka, pelopor pengajaran Islam murni, pelopor amal usaha bidang sosial dan pendidikan dan pelopor kebangkitan wanita Indonesia melalui wadah Aisyiyah (Saidah, 2016). Menurut Febriansyah dkk (dalam Saidah, 2016:192), gebrakan selanjutnya yang dilakukan K.H. Ahmad Dahlan pada tahun 1910 adalah mendirikan sebuah madrasah yang memberikan pengajaran gabungan antara ilmu agama dan ilmu umum yang diselenggarakan di ruang tamu rumahnya.

Gagasan tersebut merupakan upaya untuk mencapai tujuan dari proses pendidikan Islam yang hendaknya mengakomodasi berbagai ilmu pengetahuan, baik umum ataupun agama, untuk mempertajam daya intelektualitas dan memperkokoh spiritualitas peserta didik melalui sebuah Madrasah Muhammadiyah (Putra, 2020: 102). Berbekal ilmu yang mumpuni, K.H. Ahmad Dahlan mendirikan organisasi Muhammadiyah untuk menyebarkan ajaran Islam yang murni, seperti yang dicontohkan Nabi Muhammad Saw, tanpa tercampur kepercayaan animisme (kepercayaan kepada roh yang mendiami semua benda) dandinamisme (meyakini semua benda yang ada di dunia memiliki kekuatan gaib) (Putra, 2020: 102).

Dalam mewujudkan pemikiran pendidikan K.H. Ahmad Dahlan, maka dibutuhkan lingkup materi seperti yang ditulis oleh Dr. Abdullah Nashih Ulwan, dengan tujuh lingkup materi pendidikan Islam. Tujuh lingkup materi pendidikan menurut Dr. Abdullah Nashih Ulwan yaitu Pendidikan Keimanan, Pendidikan Moral/Akhlak, Pendidikan Jasmani/Fisik, Pendidikan Rasio, Pendidikan Kejiwaan/Hati Nurani, Pendidikan Sosial/Kemasyarakatan dan Pendidikan Seksual (Lestari, 2017 : 21).

Pemikiran pendidikan K.H. Ahmad Dahlan telah banyak diteliti oleh penulis lain sebelumnya. Salah satunya yaitu dari Kiki Gusti Lestari mengenai konsep pendidikan islam menurut Ahmad Dahlan. Dalam landasan teori pada penelitian Kiki, dituliskan kurikulum pendidikan Islam yaitu materi dan kurikulum mengandung arti yang sama, meliputi bahanbahan pelajaran yang disajikan dalam proses kependidikan dalam suatu sistem institusional 
pendidikan. Pokok pelajaran yang disajikan dalam proses pendidikan Islam secara formal dan nonformal diambil dari bahan materi yang berpedoman pada Al-Qur'an. Dengan demikian, pentingnya meyakini, memahami, menghayati dan mengamalkan materi pendidikan Islam dalam kehidupan sehari-hari (Lestari, 2017: 20).

Menurut Dr. Abdullah Nashih Ulwan, anak adalah sebuah anugerah istimewa bagi semua orang tua. Atas izin Allah, setiap orang tua dikaruniai sebuah anak yang mungkin sulit ketika diminta dan dirahasiakan kelahirannya. Selain itu, anak juga merupakan amanah bagi orang tuanya, agar dapat terpelihara, terdidik dan dibina hingga tumbuh sebagai anak-anak yang berkualitas. Dengan demikian, memiliki kekuatan dan ketahanan sebagai bekal mengarungi hidup di masa depannya (Tijani, 2009: 129-130).

Dalam buku tulisan Abdullah Nashih Ulwan berjudul 'Tarbiyatul Aulad Fil Islam' menyatakan bahwa terdapat satu cara dalam mewujudkan seorang anak agar menjadi dambaan hati dan memberikan kebaikan pada setiap orang tua adalah melalui pendidikan yang bersumber dari sebuah nilai Islam. Konsep pendidikan serta pembinaan anak, bahkan sejak dalam kandungan pun telah ditegaskan dalam Islam, sehingga seorang anak dapat tumbuh menjadi sosok yang mencintai Allah dan Rasul-Nya, serta berbakti kepada orang tua (Tijani, 2009: 129-130). Dr. Abdullah Nasikh Ulwan menyampaikan lingkup materi pendidikan Islam terdiri dari tujuh unsur yaitu Pendidikan Keimanan, Pendidikan Pendidikan Moral/Akhlak, Pendidikan Fisik/Jasmani, Pendidikan Rasio, Pendidikan Kejiwaan/Hati Nurani, Pendidikan Sosial/Kemsyarakatan dan Pendidikan Seksual (Lestari, 2017: 21). Pendidikan harus mengandung hal-hal dimana tujuan pendidikan yang sempurna adalah untuk melahirkan individu yang menguasai ilmu agama dan ilmu umum, material dan spiritual serta dunia dan akhirat dengan berusaha mengembalikan ajaran Islam kepada sumbernya yaitu al-Quran dan Hadits sebagai upaya untuk menyelamatkan umat Islam agar merubah menuju pemikiran yang dinamis, cerdas, kritis dan memiliki daya analisis tajam dalam memetakan dinamika kehidupan pada masa depan (Lestari, 2017: 21-22).

Berdasarkan uraian latar belakang, maka identifikasi masalah yang dibahas adalah pemikiran pendidikan Dr. Abdullah Nashih Ulwan dalam mewujudkan pemikiran pendidikan K.H. Ahmad Dahlan dalam memadukan ilmu agama dan ilmu umum agar mampu memetakan dinamika kehidupan. Hal ini berarti bahwa urgensi penelitian ini penting sebagai bagian dalam menjelaskan pendangan pendidikan tokoh pendidikan di Indonesia. 


\section{Metode Penelitian}

Penulis menggunakan metode penelitian pustaka/riset kepustakaan (library research). Riset pustaka memerlukan sumber perpustakaan untuk memperoleh data penelitiannya. Tegasnya riset pustaka membatasi kegiatannya hanya pada bahan-bahan koleksi perpustakaan saja tanpa memerlukan riset lapangan (Zed, 2014 : 1-2) dan penelitian Kiki Gusti Lestari mengenai Konsep pendidikan Islam menurut Ahmad Dahlan menggunakan metode penelitian kualitatif dan kepustakaan (Library Research). Penelitian ini bertujuan untuk mengetahui hubungan pemikiran pendidikan K.H. Ahmad Dahlan dengan lingkup materi pendidikan Islam Dr. Abdullah Nashih Ulwan dalam memadukan ilmu agama dan ilmu umum untuk mewujudkan manusia yang mampu memetakan dinamika kehidupan.

\section{Pembahasan}

\section{Teori Pendidikan}

Dalam Bahasa Indonesia terdapat istilah pendidikan berasal dari kata "didik" dengan awalan "pe" dan akhiran "an" yang mengandung arti cara, proses atau perbuatan mendidik. Istilah pendidikan berasal dari kata "paedagogie" yakni membimbing, maka dapat disimpulkan pedagogi dari bahasa Yunani adalah bimbingan yang diberikan kepada anak. Selanjutnya, istilah pendidikan berkembang menjadi "education" dengan arti bimbingan atau pengembangan yang berasal dari Bahasa Inggris (Jamhari, 2016: 7).

Pendidikan diperuntukkan kepada anak-anak dan remaja baik di sekolah maupun di kampus dengan tujuan memberikan pengetahuan dan mengembangkan keterampilan melalui tahapan pelatihan dan pengajaran. Secara luas, pendidikan berarti seluruh pengalaman belajar bagi seseorang yang berlangsung seumur hidup dalam memengaruhi pertumbuhan individu (Saidah, 2017). Definisi pendidikan menurut KI Hajar Dewantara adalah proses menuntun anak-anak sesuai kodrat yang ada pada dirinya dengan tujuan kemaslahatan dan kehidupan yang bahagia sebagai sosok manusia serta anggota masyarakat (Solichah, 2018: 24).

Dalam Islam, pendidikan merupakan hal yang fundamental. Menurut pendapat Rasyid Ridha bahwa adanya kesamaan kewajiban menuntut ilmu bagi perempuan dan laki-laki yang merupakan kesepakatan dari para ulama. Seluruh masyarakat dengan stuktur sosial, politik dan ekonomi yang berbedapun berkeajiban untuk menuntut ilmu dan membekali diri dengan ilmu serta mengkondisikan diri untuk melaksankaan kewajiban menuntut ilmu dengan sempurna. 
Oleh sebab itu, tujuan pendidikan menurut Islam ditunjukan melalui cerminan tujuan hidup manusia yaitu untuk beribadah kepada Allah S.W.T dan menjadi sosok pemimpin di bumi (Solichah, 2018: 24).

\section{Teori Pendidikan Islam}

Pendidikan Islam didefinisikan sebagai proses transformasi dan internalisasi ilmu pengetahuan dan nilai-nilai pada diri anak didik melalui pengembangan dan penumbuhan potensi fitrahnya guna mencapai keselarasan dan kesempurnaan hidup dalam segala aspeknya. Namun, terdapat beberapa problem dalam pelaksaannya yang menyebabkan tujuan dari Pendidikan Islam tidak tercapai. Problem tersebut terbagi dua macam, yaitu problem internal dan problem eksternal. Dalam upaya mengatasi berbagai permasalahan dalam proses penerapan pendidikan Islam tersebut, maka ditetapkan urgensi Undang-Undang Sistem Pendidikan Nasional sebagai kebijakan Negara untuk memberikan kesempatan yang terbuka terhadap pelaksanaan pendidikan Islam (Awwaliyah dan Baharun, 2019: 35)

Menurut Islam, kepada semua umatnya untuk mendayagunakan semua kemampuan yang ada pada dirinya dalam 8 rangka memahami fenomena alam semesta. Ilmu pengetahuan dapat diperoleh jika sumber daya manusia mendayagunakan berbagai media, baik yang diperoleh melalui persepsi inderawi, kalbu, akal, wahyu maupun ilham. Oleh karena itu, aktifitas pendidikan dalam Islam hendaknya memberikan kemungkinan yang sebesar-besarnya bagi pengembangan ke semua dimensi tersebut (Indrawan dan Barkah, 2018: 7-8). Pendidikan Islam bertujuan untuk membentuk manusia sempurna (al-insan al-kamil). Hendaknya pendidikan Islam mengarahkan kepada dua dimensi, yaitu adanya dimensi dialektika horisontal antar sesama manusia serta dimensi ketundukan vertikal yang ditujukan pada Allah. Hal ini sesuai dengan pendapat Hamzah dan Samsul Nizar.

Secara etimologis, pendidikan Islam memiliki istilah yang terdiri dari atas dua kata, yaitu "pendidikan" dan "islami". Definisi pendidikan sering disebut dengan berbagai istilah, antara lain altarbiyah, al-taklim, al-ta'dib dan al-riyadoh. Adanya perbedaan kontek kalimatnya dalam pengunaan istilah tersebut, maka setiap istilah memiliki makna yang berbeda-beda. Namun dalam situasi tertentu, beberapa istilah tersebut dapat mengandung makna pendidikan yang sama (Gunawan, 2014: 1-2). 
Jurnal Humanitas

Vol. 6 No. 2, Juni 2020, hal. 132-143

\section{Biografi Ahmad Dahlan}

Pada tanggal 1 Agustus 1868 merupakan hari kelahiran K.H Ahmad Dahlan tepatnya di Kauman, Yogyakarta. Ia terlahir dari seorang ayah yang bernama K.H Abu Bakar bin Kiai Sulaiman yang merupakan seorang ulama dan khatib terkemuka di Masjid Besar Kesultanan Yogyakarta serta seorang ibu yang bernama Siti Aminah yang merupakan Puteri H. Ibrahim sebagai penghulu Kesultanan Yogyakarta. Nama lengkap beliau adalah Muhamamd Darwis (Rohmadi, 2017: 7).

Latar belakang pemikiran pendidikan Kyai Haji Ahmad Dahlan berangkat dari tujuan pendidikan yang saling bertentangan pada saat itu, yaitu pendidikan pesantren dan pendidikan sekolah model Belanda.Tujuan pendirian pesantren hanyalah untuk mewujudkan manusia yang shalih dalam beragama. Sedangkan, pendidikan sekolah model Belanda tidak memiliki materi agama dalam pengajarannya sehingga termasuk sebagai pendidikan sekuler (Mawardi, 2016: 94).

Berdasarkan pernyataan pemikiran KH. Ahmad Dahlan di atas, dapat dilihat sebagai dorongan kepada generasi muda Islam agar dapat berjuang mempertahankan Islam di Indonesia sebagai keyakinan yang tertanam pada dirinya. Lahirlah usaha-usaha yang ditujukan untuk mewujudkan tujuan Muhammadiyah yang sudah dimulai sejak memasuki abad ke dua (1912-2014), diantaranya menjunjung serta menegakkan agama Islam sesuai pedoman AlQur'an dan sunnah, sehingga terwujudnya masyarakat Islam yang sebenar- benarnya (Mawardi, 2016: 94).

\section{Konsep Pendidikan Islam K.H. Ahmad Dahlan}

Berdasarkan pandangan K.H. Ahmad Dahlan, pendidikan adalah upaya strategis untuk menyelamatkan umat Islam dari kejumudan berpikir yang terjadi pada masyarakat Islam umumnya (Mawardi, 2016: 94-95). Konsep pendidikan Islam menurut K.H. Ahmad Dahlan adalah bermula dari mengajarkan pendidikan agama Islam di sekolah yang telah didirikannya. Pada tahun 1911, ide K.H Ahmad Dahlan diwujudkan dengan pendirian sekolah agama di Kauman menggunakan referensi metode Barat, misalnya dalam penggunaan kursi, bangku dan kertas. Melalui ide tersebut menyebabkan banyak lembaga pendidikan mulai mengikuti metode yang diterapkannya pada waktu itu, serta memasukan pendidikan agama Islam sebagai salah satu mata pelajaran yang harus diikuti oleh setiap peserta didik (Fitrohadi, 2015: 6). 
Kebijakan pemerintah kolonial sejak timbulnya Politik Etis banyak mendirikan lembaga pendidikan. Tujuannya bukanlah untuk memajukan bangsa Indonesia, tetapi hanya untuk kepentingan mereka menghasilkan tenaga terampil untuk kelanggengan imperalisme dan dapat dijadikan buruh. Buah didikannya menimbulkan semangat intelektualisme, materialisme dan egoisme. Sehingga, K.H Ahmad Dahlan mengkhawatirkan pengaruh pemikiran Islam akan lenyap dari generasi muda (Abbas, 2020: 94).

Menurut K.H Ahmad Dahlan, menciptakan individu yang memiliki kemampuan dalam menguasai perpaduan ilmu umum dan ilmu agama, spiritual, dunia serta akhirat merupakan tujuan sempurna dalam konteks pendidikan. Maka, tidak dapat dipisahkan antara dua hal tersebut. Alhasil, Ahmad Dahlan berupaya mengajarkan perpaduan pengetahuan umum dan agama sekaligus di Madrasah Muhammadiyah (Mawardi, 2016: 94).

\section{Pemikiran Pendidikan Dr. Abdullah Nashih Ulwan}

Persyarikatan Muhammadiyah mengembangkan pendidikan kecerdasan intelektual di samping segi-segi moral dan keagamanan Pokok pelajaran yang disajikan dalam pelaksanaan pendidikan Islam secara formal dan nonformal diambil dari bahan materi yang berpedoman pada Al-Qur'an. Materi yang bersumber dari al-Qur'an sebagai pendidikan Islam harus dipahami, dihayati, diyakini dan diamalkan dalam kehidupan umat Islam yang sesuai dengan lingkup materi Dr. Abdullah Nashih Ulwan (Fadli dan Djollong, 2018: 94).

Damaskus, Syria yakni Bandar Halab (Aleppo) tepatnya di Qadhi Askar adalah daerah kelahiran Abdullah Nashih Ulwan pada tahun 1928. Beliau terlahir dari keluarga yang taat agama serta memprioritaskan akhlak Islam dalam bermasyarakat. Beliau sangat cemerlang dalam studinya dan selalu menjadi referensi berharga bagi rekan-rekannya di madrasah. Hal ini dapat ditunjukkan dengan riwayat pendidikannya, ia memperdalam studinya di Universitas Al-Azhar dalam bidang pendidikan (tarbiyah) pada tahun 1954 (Nasrullah, 2016: 52-54).

Abdullah Nashih Ulwan merupakan sosok dai dan ulama. Kepedulian dan gagasan beliau dalam konsep metode pendidikan yang bercirikan pada penekanan tujuan untuk pendidik yang berperan aktif. Sebab, proses pembelajaran yang bermula dari sosok pendidik aktif agar terpenuhinya tujuan pembelajaran dan menjadikan anak didik sebagai generasi Islam yang baik (Rahayu dan Mukhlas, 2016: 93). Dalam buku tulisan Abdullah Nashih Ulwan berjudul 'Tarbiyatul Aulad Fil Islam' menyatakan bahwa terdapat satu cara dalam 
mewujudkan seorang anak agar menjadi dambaan hati dan memberikan kebaikan pada setiap orang tua adalah melalui pendidikan yang bersumber dari sebuah nilai Islam (Tijani, 2009: 129-130).

Dalam mewujudkan pemikiran pendidikan K.H. Ahmad Dahlan, maka berkaitan dengan lingkup materi pendidikan Islam seperti yang ditulis oleh Dr. Abdullah Nashih Ulwan, antara lain Pendidikan Keimanan yang mencangkup keimanan kepada Allah, Malaikat, Kitab, Nabi/Rasul, Hari Akhir dan Takdir Allah, Pendidikan Moral/Akhlak sebagai latihan membangkitkan nafsu ketuhanan dan meredam nafsu perilaku tercela Ahmad Dahlan berupaya mengajarkan perpaduan pengetahuan umum dan agama sekaligus di Madrasah Muhammadiyah (Mawardi, 2016: 94). Berikut tujuh lingkup materi yang hendaknya ditanamkan oleh orangtua kepada anak melalui dunia pendidikan berdasarkan lingkup materi pendidikan Islam seperti yang ditulis oleh Dr. Abdullah Nashih Ulwan (Tijani, 2009: 177179), yaitu:

\section{Pendidikan Keimanan}

Seorang anak dibimbing dengan berlandaskan pemahaman dan pendidikan Keimanan. Dimulai dari orang tua yang mengenalkan kehidupan anak dengan kalimat 'Laa ilaha illa Allah'. Dengan begitu, anak akan mendalami makna rukum iman, menjalankan ibadah, mencintai Nabi-Nya, mengetahui hukum Islam dengan keyakinan yang telah ditanamkan atas dasar kecintaan Hamba kepada Allah.

2. Pendidikan Moral/Akhlak

Adanya pendidikan moral dan akhlak dapat membimbing seorang anak menjadi sosok yang sopan dan santun serta mengamalkan perilaku-perilaku mulai di dalam setiap langkah kehidupannya.

\section{Pendidikan Fisik}

Pendidikan fisik memberikan pengetahuan bagi seorang anak untuk bertanggung jawab dalam menjaga kebugaran fisiknya, menciptakan muslim yang kuat, sehat bersemangat dan bergairah. Peran orang tua juga sangat dibutuhkan dalam mencapai tujuan ini, antara lain melalui pemberian kelayakan hidup dari nafkah yang halal dan baik kepada anak, mengenali adab-adab dalam berkehidupan seperti adab makan, minum dan tidur, mengajak untuk hidup sehat dengan melatih peregangan otot melalui olahraga. 


\section{Pendidikan Rasio}

Hadir harapan setiap orang tua untuk anaknya agar memiliki pengalaman dan ebkal ilmu yang bermanfaat, sehingga di kemudian hari dapat memberi kebermanfaatan bagi banyak orang serta menjadi lading pahala bagi orang tua tanpa putus. Dengan begitu, bekal yang sangat penting dalam kehidupan ini adalah sebuah ilmu pengetahuan yang diperoleh, mulai dari anak-anak hingga dewasa sekalipun.

\section{Pendidikan Psikis/Kejiwaan}

Pendidikan kejiwaan bertujuan untuk memberikan kemudahan anak agar dapat bersikap berani, tidak berputus asa, percaya diri, mampu mengontrol emosi dan suka berbuat kebaikan sebagai cerminan akhlak mulia. Hal tersebut menjadi tanggung jawab bagi orang tua yang hendaknya mendidik dan menanamkan nilai-nilai Islam sebagai pedoman hidup.

\section{Pendidikan Sosial}

Dalam pendidikan sosial diharapkan anak dapat menjadi sosok berjiwa sosial. Melalui berbagai cara seperti dengan bergaul kepada orang-orang di sekitar, bersikap baik dan mengharagai kepada sesama, memelihara hak orang lain. Hal ini dapat menjadi pelaksanaan perilaku sosial yang mulia dalam lingkup materi pendidikan sosial.

\section{Pendidikan Seksual}

Pendidikan Seksual mengajarkan sebuah pentingnya manusia mengenali pengetahuan dalam masalah-masalah seksual. Bahkan, seorang anak hendaknya dapat menyadari masalah-masalah yang berkenaan dengan seks, syahwat, dan perkawinan agar tidak akan terjerumus dalam lembah yang menyesatkan ketika ia tumbuh dewasa tanpa mengetahui batasan serta pembeda antara mana yang haram dan halal.

Dalam mewujudkan pemikiran pendidikan K.H. Ahmad Dahlan, maka berkaitan dengan lingkup materi pendidikan Islam seperti yang ditulis oleh Dr. Abdullah Nashih Ulwan, antara lain Pendidikan Keimanan yang mencangkup keimanan kepada Allah, Malaikat, Kitab, Nabi/Rasul, Hari Akhir dan Takdir Allah, Pendidikan Moral/Akhlak sebagai latihan membangkitkan nafsu ketuhanan dan meredam nafsu perilaku tercela, keimanan, kecakapan sosial, nilai-nilai budi pekerti luhur dan akhlak mulia, kecerdasan individu serta penanaman budaya bangsa Indonesia sebagai ciri khas bangsa. Seperti lingkup materi Dr. Abdullah Nashih Ulwan yaitu Pendidikan Keimanan, Pendidikan Pendidikan Moral/Akhlak, Pendidikan Fisik/Jasmani, Pendidikan Rasio, Pendidikan Kejiwaan/Hati Nurani, Pendidikan 
Sosial/Kemsyarakatan dan Pendidikan Seksual. Maka, penulis menyimpulkan bahwa lingkup materi Dr. Abdullah Nashih Ulwan sesuai untuk menerapkan pemikiran pendidikan K.H. Ahmad Dahlan dalam memadukan ilmu agama dan ilmu umum untuk mewujudkan manusia yang mampu memetakan dinamika kehidupan.

\section{Kesimpulan}

Berdasarkan pembahasan yang telah dikemukakan, maka dapat diambil simpulan bahwa pendidikan Islam merupakan upaya strategis untuk menyelamatkan umat Islam agar menuju pemikiran yang dinamis, cerdas, kritis, dan memiliki daya analisis tajam dalam memetakan dinamika kehidupan pada masa depan sesuai dengan pandangan K.H. Ahmad Dahlan sebagai tujuan pendidikan yang sempurna dengan melahirkan individu yang menguasai ilmu agama dan ilmu umum, material dan spiritual serta dunia dan akhirat. Pendidikan yang disajikan menggunakan materi pengajaran yang berpedoman pada Al-Qur'an dan Hadits, menulis, membaca, berhitung, menggambar serta ilmu bumi. Sehingga, dapat mengembalikan ajaran Islam kepada sumbernya yaitu al-Qur'an dan Hadits. Pemikiran pendidikan K.H. Ahmad Dahlan sudah dilaksanakan di Indonesia saat ini yang dikenal dengan kurikulum 2013 dan dengan adanya sekolah-sekolah Islam yang memadukan antara kurikulum umum dengan kurikulum Islami dengan diajarkannya pendidikan non akademik seperti pemahaman mengenai keimanan, kecakapan sosial, nilai-nilai budi pekerti luhur dan akhlak mulia, kecerdasan individu serta penanaman budaya bangsa Indonesia sebagai ciri khas bangsa.

\section{Daftar Rujukan}

Abbas, E. (2020). Pembaharuan Pendidikan Perspektif Ahmad Dahlan. Ri'ayah: Jurnal Sosial dan Keagamaan, 5(02), 216-229.

Anwar, F. (2019). "Kenapa makin ramai siswa berani bully guru di sekolah?" http://www.health.detik.com. Diakses pada tanggal 14 Februaru 2021.

Awwaliyah, R., \& Baharun, H. (2019). Pendidikan Islam dalam sistem pendidikan nasional (Telaah epistemologi terhadap problematika pendidikan Islam). JURNAL ILMIAH DIDAKTIKA: Media Ilmiah Pendidikan dan Pengajaran, 19(1), 34-49.

Fadli, M., \& Djollong, A. F. (2018). Jurnal, Konsep Pendidikan Menurut KH. Ahmad Dahlan. Istiqra: Jurnal Pendidikan dan Pemikiran Islam, 5(2).

Gunawan, H. (2014). Pendidikan Islam Kajian Teoritis dan Pemikiran Tokoh. Bandung: PT Remaja Rosdakarya. 
Indrawan, H. \& Januar Barkah. (2018). KH. Ahmad Dahlan Perannya Dalam Membangun Sistem Pendidikan, Alur Sejarah: Jurnal Pendidikan Sejarah, 3(1).

Jamhari. (2016). Implikasi Pemikiran Pendidikan KH. Ahmad Dahlan Terhadap Perkembangan Pendidikan Islam di Indonesia. Skripsi Banten: Program Strata Satu Institut Agama Islam Negeri Sultan Maulana Hasanuddin.

Lahitani, S. Viral, Kaka Ajari Adiknya Membaca Iqra Sambil Berjualan. https://www.liputan6.com/citizen6/read/4448641/viral-kakak-ajari-adiknya-membacaiqra-sambil-berjualan-balon. Diakses pada tanggal 14 Februari 2021.

Lestari, K.G. (2017). Konsep pendidikan islam menurut Ahmad Dahlan. Skripsi. Palembang: Program Strata Satu Sekolah Tinggi Ilmu Tarbiyah Raudhatul Ulum.

Mawardi, A. (2016). Studi Pemikiran Pendidikan KH. Ahmad Dahlan. TARBAWI: Jurnal Pendidikan Agama Islam, 1(2), 94-102.

Nasrullah, R. (2016). Analisis Nilai-Nilai Pendidikan dalam Kitab Tarbiyatul Aulad Fil Islam Karya Abdullah Nashih Ulwan dan Relevansinya Terhadap Pendidikan Karakter, Skripsi. Malang: Program Strata Satu Universitas Islam Negeri (UIN) Maulana Malik Ibrahim.

Nida, N. H. (2020). Perilaku Seks Pranikah Remaja. https://www.dp3ap2.jogjaprov.go.id/ . Diakses pada tanggal 14 Februari 2021.

Nizar, S. (2008). Memperbincangkan Dinamika Intelektual dan Pemikiran Hamka tentang Pendidikan Islam. Jakarta: Prenada Media Group.

Putra, D. W. (2018). konsep pendidikan Islam dalam perspektif KH Ahmad Dahlan. Tarlim: Jurnal Pendidikan Agama Islam, 1(2), 99-107.

Rahayu, S. dan Moh. Mukhlas. (2016). Tujuan dan Metode Pendidikan Anak: Perspektif Abdullah Nashih Ulwan dan Pauolo Freire, dJurnal Kependidikan Dasar Islam Berbasis Sains, 1(1), 83-96.

Rohmadi, H. (2017). Konsep Pendidikan Islam Menurut Kyai Haji Ahmad Dahlan. Skripsi. Surakarta: Program Strata Satu Universitas Muhammadiyah Surakarta.

Saidah. (2016). Pengantar Pendidikan. Jakarta: Rajawali Pers.

Sholichah, A. S. (2018). Teori-teori pendidikan dalam Al-Qur'an. Edukasi Islami: Jurnal Pendidikan Islam, 7(01), 23-46.

Sunaryo, E. (2020). Siswa/i SMKN 01 Rambah, Rayakan Kelulusan Dengan Berbagi Takjil Ke Rumah Warga. http://catatanriau.com/news/detail/2871/pendidikan/rohul/siswa-ismkn-01-rambah-rayakan-kelulusan-dengan-berbagi-takjil-kerumah-warga. Diakses pada tanggal 14 Maret 2021.

Tijani, A. (2009). Konsep Pendidikan Anak Sholeh Perspesktif Abdullah Nashih Ulwan. Skripsi. Surabaya: Program Strata Satu Institut Agama Islam Negeri Sunan Ampel.

Wibisono, Y. (2020). Jelang UN, Murid SMA/SMK di Jombang Gelar Doa Bersama https://beritajatim.com/pendidikan-kesehatan/jelang-un-murid-sma-smk-di-jombanggelar-doa-bersama/. Diakses pada tanggal 14 Maret 2021. 
Jurnal Humanitas

Vol. 6 No. 2, Juni 2020, hal. 132-143

Zed, M. (2014). Metode Penelitian Kepustakaan. Jakarta: Yayasan Pustaka Obor Indonesia. 